\title{
EVALUASI KINERJA GURU DALAM MENGIMPLEMENTASIKAN PENDEKATAN SAINTIFIK KURIKULUM 2013 PADA SMA SE-KOTA SINGARAJA
}

\author{
Dewa Ayu Sri Antari \\ Jurusan Pendidikan Ekonomi, Fakultas Ekonomi \\ Universitas Pendidikan Ganesha Singaraja, \\ Indonesia
}

email :dewaayu3737@gmail.com

\begin{abstract}
Abstrak
Penelitian ini bertujuan untuk mengetahui kinerja guru ekonomi dalam mengimplementasikan pendekatan saintifik kurikulum 2013 pada SMA se-kota Singaraja. Subjek dalam penelitian ini adalah guru ekonomi pada SMA se-kota Singaraja, sedangkan yang menjadi objek dalam penelitian ini adalah implementasi pendekatan saintifik. Metode pengumpulan data yang digunakan dalam penelitian ini menggunakan wawancara dan observasi. Data yang didapat dari metode wawancara dan observasi kemudian dianalisis dengan teknik deskriptif. Hasil penelitian kinerja guru ekonomi dalam mengimplementasikan pendekatan saintifik kurikulum 2013 pada SMA se-kota Singaraja sudah cukup baik pada mata pelajaran ekonomi, dan terdapat dua guru dari tujuh guru ekonomi pada SMA se-kota Singaraja yang sudah baik dalam mengimplementasikan pendekatan saintifik kurikulum 2013.
\end{abstract}

Kata kunci : kinerja guru, kurikulum 2013, pendekatan saintifik.

\section{Abstract}

This research aimed to determine performance economics teachers in implementation a scientific curriculum 2013 in SMA Singaraja City. Subjects in this research are economic teachers in SMA Singaraja city, while the object in this research is the implementation of scientific approach. Data collected in this research using interview and observation. Data obtained from interview and observation than analyzed by descriptive analysis technique. The result performance economics teachers in implementation a scientific of curriculum 2013 in SMA Singaraja City is good on economic subjects and than two teachers from seven economics teachers SMA Singaraja city who are good at implementing scientific approach of curriculum 2013.

Keywords: teacher performance, curriculum 2013, scientific approach.

\section{PENDAHULUAN}

Kurikulum 2013 menggunakan pendekatan saintifik karena pendekatan ini dinilai sesuai dengan kemampuan sikap, pengetahuan, dan keterampilan siswa. Dalam penerapan pendekatan saintifik proses kegiatan pembelajaran menuntut siswa agar aktif dalam belajar, sehingga guru memiliki peran penting sebagai pemandu siswa. Di dalam Kementerian Pendidikan dan Budaya tahun 2013 dalam Peraturan Menteri Pendidikan dan Kebudayaan nomor 65 Tahun 2013 tentang Standar Proses dinyatakan bahwa standar proses pembelajaran pada kurikulum 2013 menggunakan pembelajaran dengan pendekatan saintifik, tematik terpadu, dan tematik. Pembelajaran pendekatan saintifik memiliki tahaptahapan yaitu mengamati, merumuskan pertanyaan, mengumpulkan data, menganalisis data, dan mengkomunikasikan.Dengan adanya peraturan menteri tentang penerapan pendekatan saintifik diharapkan guru mampu memberikan ensensi yang baik dan mengimplementasikan semua tahap-tahapan pendekatan saintifik dalam kegiatan pembelajaran sehingga, peserta didik mampu memahami materi yang disampaikan.

Hasil observasi pada Sekolah Menengah Atas (SMA) di Kota 
Singaraja yang menerapkan kurikulum 2013, guru menyatakan bahwa proses pembelajaran sudah menggunakan pendekatan saintifik, guru masih mengalami kesulitan dalam mengimplementasikan dikarenakan oleh pelatihan tersebut tidak melibatkan semua guru untuk mengikuti pelatihan dan sosialisasi kurikulum 2013. Pelatihan tersebut hanya melibatkan perwakilan dari masing-masing guru di masing-masing sekolah sebanyak 2 guru. Guru perwakilan yang mengikuti pelatihan kurikulum 2013 akan menjelaskan kepada guru lainnya yang ada di sekolah masing-masing mengenai penerapan pembelajaran menggunakan pendekatan saintifik.

Guru masih merasa kesulitan dalam proses pembelajaran, hal ini dapat dilihat dari proses belajar mengajar yang belum sesuai. Di dalam pelaksanaan pembelajaran pada kurikulum 2013 guru harus menggunakan pendekatan saintifik, tetapi pada kenyataannya di lapangan guru masih mengalami kesulitan yaitu membangun keaktifan siswa untuk memulai bertanya atau untuk memulai berfikir secara kreatif karena dalam prakteknya guru masih mengedepankan aspek kognitif, padahal dalam kurikulum 2013 aspek yang paling penting yang harus dikembangkan pada siswa adalah aspek afektif dan aspek keterampilan, maka perlu kiranya dilakukan sebuah evaluasi lebih mendalam apakah guru mampu mengimplementasikan pendekatan saintifik kurikulum 2013, sehingga apa yang menjadi tujuan dari diterapkannya kurikulum 2013 dapat tercapai dengan baik.

Evaluasi dilakukan dengan berpedoman pada tahap-tahapan pendekatan saintifik. Kemendikbud 2013 dalam Peraturan Menteri Pendidikan dan Kebudayaan nomor 65 Tahun 2013 tentang Standar Proses dinyatakan bahwa standar proses pembelajaran pada kurikulum 2013 menggunakan pembelajaran dengan pendekatan saintifik, tematik terpadu, dan tematik. Pembelajaran pendekatan saintifik memiliki tahap-tahapan yaitu mengamati, merumuskan pertanyaan, mengumpulkan data, menganalisis data, dan mengkomunikasikan. Dengan adanya peraturan Menteri tentang penerapan pendekatan saintifik diharapkan guru mampu memberikan ensensi yang baik dan mengimplementasikan semua tahaptahapan pendekatan saintifik dalam kegiatan pembelajaran sehingga, peserta didik mampu memahami materi yang disampaikan.

Menurut Soetjipto (2003:32) "Perancangan sistem penilaian kinerja pada dasarnya merupakan perancangan suatu sistem formal dan terstruktur untuk mengukur dan mengevaluasi tidak hanya hasil kerja tetapi juga sikap, prilaku, pengetahuan dan keterampilan/ keahlian kerja sumber daya manusia". Mengukur baik buruknya kinerja guru dapat diukur melaui satu indikator utama yakni kompetensi profesi yang dimiliki oleh seorang guru.Begitu juga keberhasilan seorang guru bisa dilihat apabila kriteria-kriteria yang ada telah tercapai secara keseluruhan jika kriteria telah tercapai berarti pekerjaan seseorang telah dianggap memiliki kualitas kerja yang baik.

Istilah evaluasi berasal dari kata serapan bahasa inggris yakni evaluation yang artinya penilaian atau penafsiran. "evaluasi adalah pemberian nilai terhadap kualitas sesuatu" (Purwanto, 2002:23). Lebih lanjut Arikunto dan Jabar (2010) menegaskan evaluasi adalah kegiatan untuk mengumpulkan informasi tentang pekerjaannya, yang selanjutnya informasi tersebutdigunakan untuk menentukan alternatif yang tepat dalam mengambil keputusan. Fungsi utama evaluasi dalam hal ini adalah menyediakan informasi-informasi yang berguna bagi pihak decision maker untuk menetukan kebijakan yang akan diambil berdasarkan evaluasi yang telah dilakukan. Penilaian prestasi kerja (performance appraisal) adalah proses melalui mana organisasi-organisasi mengevaluasi atau menilai prestasi kerja karyawan (Hani, 2000). 
Kinerja guru dapat dilihat dan diukur berdasarkan spesifikasi atau kriteria kompetensi yang harus dimiliki oleh setiap guru. Berkaitan dengan kinerja, wujud prilaku yang dimaksud adalah kegiatan guru dalam proses pembelajaran. Keterangan lain menjelaskan dalam Undang-undang No. 14 Tahun 2005 Bab IV Pasal 20 (a) tentang Guru dan Dosen menyatakan bahwa standar prsetasi kerja guru dalam melaksanakan tugas keprofesionalannya, guru berkewajiban merencanakan pembelajaran, melaksanakan proses pembelajaran yang bermutu serta menilai dan mengevaluasi hasil pembelajaran. Tugas pokok guru tersebut yang diwujudkan dalam kegiatan belajar mengajar merupakan bentuk kinerja guru. Guru perlu memiliki pengetahuan yang memadai tentang pendekatan saintifik (Ridwan, 2014).

$$
\text { Menurut Martoyo (2007) }
$$

implementasi merupakan suatu

penerapan ide, konsep, kebijakan atau inovasi dalam suatu tindakan praktis sehingga memberikan dampak, baik berupa perubahan pengetahuan, keterampilan maupun nilai dan sikap. Implementasi kurikulum didefinisikan sebagai suatu proses penerapan ide, konsep, dan kebijakan kurikulum (kurikulum potensial) dalam suatu aktivitas pembelajaran, sehingga peserta didik menguasai seperangkat kompetensi tertentu, sebagai hasil interaksi dengan lingkungan.

Pengertian pendekatan saintifik menurut Kementerian Pendidikan dan budaya, Kurikulum 2013 menekankan diterapkannya dimensi pedagogik modern dalam pembelajaran dengan jalan menggunakan pendekatan saintifik. Pendekatan saintifik/ilmiah merupakan proses pembelajaran yang menggunakan proses berfikir ilmiah. Pendekatan ilmiah dapat dijadikan sebagai jembatan untuk perkembangan dan pengembangan sikap, keterampilan dan pengetahuan peserta didik. Kemendikbud (2012) memberikan konsepsi bahwa pendekatan ilmiah pembelajaran mencakup komponen: mengamati, menanya, mencoba, mengolah, menyajikan, menyimpulkan dan mencipta.

Tahap-tahapan dalam pendekatan saintifik sebagaimana disampaikan dalam Kemendikbud 2014 dalam lampiran Peraturan Menteri Pendidikan dan Budaya Nomor 103 Tahun 2014 yaitu. pertama mengamati dalam pembelajaran hendaklah guru membuka secara luas dan bervariasi kesempatan peserta didik untuk melakukan pengamatan, kedua menanya adalah mengajukan pertanyaan tentang informasi yang belum dipahami. Guru yang efektif mampu menginspirasi peserta didik untuk meningkatkan dan mengembangkan ranah sikap, keterampilan, dan pengetahuannya. ketiga mengumpulkan data dilakukan melalui eksperimen, membaca sumber lain selain buku teks. Kemendikbud 2014 dalam Peraturan Menteri Pendidikan dan Budaya 103 Tahun 2014 aktivitas eksplorasi dapat dilakukan melalui eksperimen, keempat menganalisis yaitu proses berfikir yang logis dan sistematis atas fakta-fakta emperis yang dapat diobservasi untuk memperoleh simpulan, dan kelima kegiatan mengkomunikasikan adalah menyampaikan hasil pengamatan, guru diharapkan memberi kesempatan kepada peserta didik untuk mengkomunikasikan apa yang telah mereka pelajari, kegiatan ini dapat dilakukan melalui menuliskan atau menceritakan apa yang ditemukan dalam kegiatan mencari informasi, mengasosiasi, dan menemukan pola.

Dalam hal ini penerapan saintifik sangat bergantung pada peran/bantuan guru, namun seiring bertambahnya tingkatan kemampuan, kedewasaan dan pendidikan siswa, peran/bantuan guru tersebut harus semakin berkurang, ini dilakukan agar siswa mampu berfikir kritis, mengkontruksi, membangun dan membuat sketsa pengetahuannya sendiri secara maksimal.Kriteria dari pendekatan saintifik salah satunya adalah mendorong dan menginspirasi siswa berpikir secara kritis, analistis, 
dan tepat dalam mengidentifikasi, memahami, memecahkan masalah, dan mengaplikasikan materi pembelajaran. Tujuan yang ingin dicapai dalam penelitian ini adalah untuk mendiskripsikan kinerja guru dalam mengimplementasikan pendekatan saintifik kurikulum 2013 Pada SMA di Kota Singaraja.

\section{METODE}

Penelitian ini merupakan penelitian deskriptif yang digunakan untuk menggambarkan kinerja guru dalam mengimplementasikan pendekatan saintifik. Menurut Sugiyono (2011) jenis penelitian deskriptif adalah penelitian yang dilakukan untuk mengetahui nilai variabel mandiri, baik satu variabel atau lebih tanpa membuat perbandingan, atau menghubungkan dengan variabel yang lain. Seluruh data diperoleh melalui pengumpulan data di lapangan dengan pengamatan difokuskan pada kinerja guru mengimplementasikan pendekatan saintifik kurikulum 2013. Dengan harapan dapat mengetahui kemampuan guru dalam mengimplementasikan pendekatan saintifik kurikulum 2013.

Subjek dalam penelitian ini adalah guru ekonomi pada SMA di Kota Singaraja yang menerapkan kurikulum 2013, sedangkan yang menjadi objek dalam penelitian ini adalah implementasi pendekatan saintifik kurikulum 2013.Teknik pengumpulan data yang digunakan dalam penelitian ini sebagai metode utama adalah wawancara dan observasi untuk melengkapi data penelitian.Kegiatan observasi yang dilakukan peneliti digunakan untuk mengambil data tentang pelaksanaan pembelajaran berupa implementasi pendekatan saintifik dalam proses belajar mengajar yang dilakukan guru baik di dalam dan diluar kelas. Dalam pengumpulan data digunakan alat bantu berupa pedoman observasi yang berkaitan dengan fokus penelitian yang diisi oleh pengawas pembina sekolah. Adapun pedoman observasi tentang pelaksanaan pembelajaran dengan pendekatan saintifik Kemendikbud 2014 dalam Peraturan Menteri Pendidikan dan Budaya Nomor 103 Tahun 2014.

Wawancara adalah teknik pengumpulan data dengan melakukan tanya jawab secara langsung dengan pengawas guru Ekonomi di sekolah mengenai implementasi pendekatan saintifik kurikulum 2013. Dalam kegiatan wawancara yang dilakukan peneliti digunakan untuk memperoleh data tentang pemahaman guru tentang konsep pendekatan saintifik. Instrumen yang dipergunakan pada penelitian ini adalah instrumen wawancara, dalam penelitian ini peneliti akan menggunakan pedoman wawancara terstruktur untuk mewawancarai pengawas bidang studi ekonomi serta menggunakan format atau blangko pengamatan untuk instrumen observasi.

Analisis yang digunakan dalam penelitian ini adalah analisis deskriptif kualitatif yang digunakan untuk menggambarkan kinerja guru dalam mengimplementasikan pendekatan saintifik dan faktor pendukung serta penghambat dalam implementasi pendekatan saintifik. Analisis data kualitatif bertujuan pada penggalian makna, penggambaran, penjelasan, dan penempatan data pada konteksnya masing-masing. Dalam suatu penelitian, data yang diperoleh dari para informan menjadi sangat penting dalam menentukan hasil akhir penelitian yang dapat dipertanggung jawabkan dari berbagai segi. Data yang penting tersebut bisa berubah menjadi sesuatu yang tak berguna apabila, data tersebut tidak memiliki validitas dan keabsahan data. Objektivitas data berkenaan dengan derajat kesepekatan atau interpersonal agreement yakni kesepekatan antara banyak orang terhadap suatu data.

Analisis data dalam penelitian deskriptif kualitatif adalah proses mencari dan menyusun secara sistematis data yang diperoleh dari hasil wawancara, catatan lapangan, dan dokumentasi dengan cara mengkoordinasikan data kedalam kategori, menjabarkan kedalam unit- 
unit, melakukan sintesa, menyusun kedalam pola, memilih mana yang penting dan akan dipelajari danmembuat kesimpulan sehingga mudah dipahami oleh diri sendiri maupun orang lain (Sugiyono 2011). Agar memudahkan proses, studi ini mengikuti model analisis kualitatif yang dikembangkan oleh Miles dan Huberman (dalam Sugiyono 2011). Mereka menyebutnya sebagai model interaktif. Alur tersebut menunjukkan secara kronologis kegiatan analisis dari tahap awal hingga tahap penarikan kesimpulan hasil studi. Sejalan dengan penelitian ini, maka teknik analisis data yang digunakan adalah teknik analisis model interaktif yang meliputi aktivitas: reduksi data (data reduction), penyajian data (data display), dan menarik kesimpulan /verifikasi (clonclusions drawing /verifying) yang dilakukan secara interaktif secara terus menerus sampai tuntas.

\section{HASILDAN PEMBAHASAN Hasil}

Hasil penelitian ini meliputi observasi yang dilakukan oleh pengawas sekolah dan peneliti serta wawancara dengan pengawas sekolah berkaitan dengan implementasi pendekatan saintifik dalam mata pelajaran ekonomi SMA di Kota Singaraja. Sekolah yang sudah menerapkan kurikulum 2013 adalah SMA Negeri 1 Singaraja, SMA Negeri 2 Singaraja, SMA Negeri 3 Singaraja, dan SMA Negeri 4 Singaraja.

Data dari hasil penelitian pada penelitian ini didapatkan melalui wawancara mendalam yang dilakukan oleh peneliti dengan narasumber yang telah dipilih sebagai berikut adalah dengan Bapak Drs. Ketut Artana, M. Si selaku pengawas sekolah di SMA Kota Singaraja. Berdasarkan wawancara mendalam yang dilakukan peneliti terhadap informan mengenai bagaimana kinerja guru dalam mengimplementasikan pendekatan saintifik kurikulum 2013 di SMA Kota Singaraja.
Guru-guru Ekonomi pada SMA di Kota Singaraja yang menerapkan kurikulum 2013 mengimplementasikan pendekatan saintifik dalam kegiatan pembelajaran tetapi tidak semua guru melakukan suatu proses implementasi yang benar mulai dari perencanaan sampai penilaian, jika guru didampingi secara kontinu guru akan melakukan lebih baik. Hal ini dipertegas lagi dengan hasil observasi pada guru-guru Ekonomi di Kota Singaraja yang mengimplementasikan Kurikulum 2013 sebagai berikut. Observasi terhadap guru SMA Negeri 1 Singaraja Ibu Ketut Eresmawati, S.Pd, M.Pd, Dalam kegiatan mengamati guru meminta peserta didik untuk membaca teks bacaan tentang materi yang akan dipelajari setelah membaca guru menjelaskan bersama-sama mengenai materi yang akan dipelajari. Langkah selanjutnya kegiatan menanya siswa diminta menanyakan hal-hal yang ingin diketahui berkaitan dengan apa yang sedang dipelajari, kegiatan mengumpulkan data guru meminta peserta didik mengerjakan soal secara individual atau di dalam kelompok, dalam kegiatan menganalisis data guru mengawasi dan membimbing siswa dalam mengerjakan soal secara individual maupun kelompok dan kegiatan terakhir yaitu mengkomunikasikan guru memberikan kesempatan kepada siswa untuk menyampaikan hasil jawabannya.

Observasi terhadap guru SMA Negeri 2 Singaraja Ibu Made Suardani, S.Pd, Guru meminta peserta didik untuk membaca teks bacaan tentang materi yang akan dipelajari setelah membaca guru menjelaskan bersama-sama mengenai materi yang akan dipelajari, selanjutnya guru menanyakan hal-hal berkaitan dengan materi yang sedang dipelajari, siswa menjawab pertanyaan dari guru. Guru meminta peserta didik mendiskusikan soal dengan teman sebangku, dan mencari jawaban dari sumber lain selain teks bacaan. Guru memberikan kesempatan kepada siswa untuk menyampaikan hasil jawabannya 
dan Bapak Drs. Nyoman Gede Darma Kusuma Kegiatan mengamati guru meminta peserta didik untuk membaca teks bacaan tentang materi yang akan dipelajari setelah membaca guru menjelaskan bersama-sama mengenai materi yang akan dipelajari, selanjutnya kegiatan menanya siswa diminta menanyakan hal-hal yang ingin diketahui berkaitan dengan apa yang sedang dipelajari, kegiatan mengumpulkan data guru meminta peserta didik mengerjakan soal dengan cara berdiskusi dengan teman sebangku, guru mengawasi dan membimbing siswa dalam mengerjakan soal dengan cara berdiskusi dengan teman sebangku, selanjutnya guru memberikan kesempatan kepada siswa untuk menyampaikan hasil jawabannya.

Observasi terhadap guru SMA

Negeri 3 Singaraja Bapak Nyoman Sudarsana, S.Pd, Kegiatan mengamati guru meminta peserta didik untuk membaca teks bacaan tentang materi yang akan dipelajari setelah membaca guru menjelaskan bersama-sama mengenai materi yang akan dipelajari, guru meminta peserta didik mengerjakan soal secara individual, guru mengawasi dan membimbing siswa dalam mengerjakan soal secara individual. Kegiatan terakhir yaitu mengkomunikasikan guru memberikan kesempatan kepada siswa untuk menyampaikan hasil jawabannya dan Bapak Drs. Ketut Setyawan, mengamati guru menjelaskan mengenai materi yang akan dipelajari, siswa mendengarkan penjelasan dari guru dan memperhatikannya, selanjutnya guru menanyakan hal-hal yang berkaitan dengan apa yang sedang dipelajari, siswa diminta membaca buku pegangan siswa dan berdiskusi dengan teman sebangku untuk menjawab soal yang diberikan guru. Peserta didik yang sudah mengetahui jawabannya diminta untuk membacakan hasil jawabannya.

Observasi terhadap guru SMA

Negeri 4 Singaraja Ibu Dra. Ida Ayu Wasanti, mengamati guru meminta peserta didik untuk membaca teks bacaan tentang materi yang akan dipelajari setelah membaca guru bertanya kepada siswa mengenai halhal yang berkaitan dengan materi yang dipelajari guru dan siswa bersamasama menjelaskan materi yang sedang dipelajari guru memberikan kesempatan kepada siswa untuk menyimpulkan materi yang sudah dipelajari hari ini, dan Ibu Dra. Sri Jayawati, mengamati guru meminta peserta didik untuk membaca teks bacaan tentang materi yang akan dipelajari setelah membaca guru menjelaskan bersama-sama mengenai materi yang akan dipelajari, selanjutnya guru bertanya kepada siswa berkaitan dengan apa yang sedang dipelajari, siswa dan guru bersamasama menjelaskan materi yang dipelajari. Guru memberikan dua contoh soal yang harus dikerjakan oleh siswa, pada proses siswa mengerjakan soal guru membimbing dan mengawasi siswa, guru meminta dua orang siswa untuk maju kedepan menuliskan jawabannya.

\section{Pembahasan}

Hasil wawancara peneliti dengan pengawas sekolah yaitu bapak Artana, menurut beliau guru-guru pada keempat sekolah ini sudah mengimplementasikan pendekatan saintifik.Pada mata pelajaran ekonomi, guru-guru ekonomi sudah mengimplementasikan pendekatan saintifik kurikulum 2013 karena kita tahu bahwa kurikulum 2013 harus menggunakan pendekatan saintifik dengan tiga model pembelajaran, dimana implementasi pendekatan saintifik ini harus dilakukan pada kegiatan inti proses belajar mengajartetapi tidak semua guru melakukan suatu proses implementasi pendekatan saintifik yang benar mulai dari perencanaan sampai penilaian, jika didampingi secara kontinu guru akan melakukan lebih baik. Implementasi pendekatan saintifik pada pembelajaran ekonomi di SMA Kota Singaraja sesuai dengan hasil observasi, implementasi pendekatan saintifik yang memiliki lima tahapan adalah sebagai berikut. 
Pertama mengamati, dalam tahap mengamati guru meminta peserta didik untuk membaca teks bacaan mengenai materi yang akan dipelajari, kedua menanya, siswa diminta menanyakan hal-hal yang ingin diketahui berkaitan dengan materi yang sedang dipelajari, ketiga mengumpulkan data, guru meminta peserta didik mengerjakan soal atau mendiskusikan suatu masalah secara induvidu maupun kelompok. keempat menganalisis data, guru mengawasi dan membimbing siswa dalam mengerjakan soal secara individual maupun kelompok, dan kelima mengkomunikasikan, guru memberikan kesempatan siswa untuk mempresentasikan jawaban yang telah dikerjakan atau didiskusikan.

Berdasarkan data tersebut, dapat dikatakan bahwa guru-guru Ekonomi pada SMA di Kota Singaraja yang menerapkan kurikulum 2013 sudah mengimplementasikan pendekatan saintifik dalam kegiatan pembelajaran tetapi tidak semua guru melakukan suatu proses implementasi yang benar mulai dari perencanaan sampai penilaian, jika guru didampingi secara kontinu guru akan melakukan lebih baik.

Berdasarkan hasil wawancara dengan pengawas sekolah dan observasi, guru ekonomi pada ke-empat sekolah yang telah menerapkan kurilkulum 2013 dan mengimplementasikan pendekatan saintifik, dalam kegiatan pembelajaran guru sudah menerapkan kelima tahapan dalam pendekatan saintifik yaitu mengamati, menanya, mengumpulkan data, menganalisis data, dan mengkomunikasikan tetapi tidak semua guru melakukan suatu proses implementasi yang benar muali dari tahap mengamati sampai mengkomunikasikan dalam implementasi pendekatan saintifik. Lebih lanjut bapak Artana menyatakan mengenai pemahaman guru mengenai pendekatan saintifik, guru ekonomi sudah cukup memahami tentang pendekatan saintifik tetapi masih perlu banyak belajar lagi karena guru butuh penyesuaian dengan kurikulum yang baru ini. Dalam kurikulum baru ini identik dengan pendekatan saintifik jadi semua guru menggunakan pendekatan tersebut walaupun belum sepenuhnya sesuai.

Guru yang sudah baik dalam mengimplementasikan pendekatan saintifik yaitu Ibu Eresmawati dari SMA Negeri 1 Singaraja dan Bapak Drs. Nyoman Gede Darma Kusuma dari SMA Negeri 2 Singaraja. Seperti yang dijelaskan pada saat wawancara sebagai berikut Guru yang sudah baik dalam mengimplementasikan pendekatan saintifik ini selama pengawasan saya adalah guru dari SMA Negeri 1 Singaraja yaitu ibu Ketut Eresmawati beliau pandai mengelola kelas dan proses pembelajaran pendekatan saintifik dengan baik beliau juga sangat kreatif dan pandai memanfaatkan waktu dengan baik. Ada pula satu guru yang saya nilai baik dalam proses pembelajaran dari SMA Negeri 2 Singaraja bapak Drs. Nyoman Gede Darma Kusuma beliau juga sudah baik dalam mengimplementasikan pendekatan saintifik kurikulum 2013.

Berdasarkan hasil penelitian yang diperoleh mengenai kinerja guru ekonomi dalam mengimplementasikan pendekatan saintifik kurikulum 2013 di SMA Kota Singaraja sudah cukup baik pada mata pelajaran ekonomi, guruguru ekonomi sudah mengimplementasikan pendekatan saintifik kurikulum 2013 karena dalam kurikulum $2013 \quad$ harus mengimplementasikan pendekatan saintifik dengan dengan lima tahap sebagaimana disampaikan dalam Permendikbud Nomor 103 tahun 2014 yaitu. pertama mengamati dalam pembelajaran hendaklah guru membuka secara luas dan bervariasi kesempatan peserta didik untuk melakukan pengamatan, kedua menanya adalah mengajukan pertanyaan tentang informasi yang belum dipahami. Guru yang efektif mampu menginspirasi peserta didik untuk meningkatkan dan mengembangkan ranah sikap, 
keterampilan, dan pengetahuannya, ketiga mengumpulkan data dilakukan melalui eksperimen, membaca sumber lain selain buku teks. keempat menganalisis yaitu proses berfikir yang logis dan sistematis atas fakta-fakta emperis yang dapat diobservasi untuk memperoleh simpulan, dan kelima kegiatan mengkomunikasikan adalah menyampaikan hasil pengamatan, guru diharapkan memberi kesempatan kepada peserta didik untuk mengkomunikasikan apa yang telah mereka pelajari, kegiatan ini dapat dilakukan melalui menuliskan atau menceritakan apa yang ditemukan dalam kegiatan mencari informasi, mengasosiasi, dan menemukan pola.

$$
\text { Guru dari SMA Negeri } 1
$$

Singaraja Ibu Eresmawati dalam mengimplementasikan pendekatan saintifik sesuai dengan Permendikbud Nomor 103 tahun 2014 yaitu pada tahapan mengamati guru meminta peserta didik untuk membaca teks bacaan tentang materi yang akan dipelajari setelah membaca guru menjelaskan bersama-sama mengenai materi yang akan dipelajari. Tahap selanjutnya kegiatan menanya siswa diminta menanyakan hal-hal yang ingin diketahui berkaitan dengan apa yang sedang dipelajari, tahap mengumpulkan data guru meminta peserta didik mengerjakan soal secara individual atau di dalam kelompok, dalam tahap menganalisis data guru mengawasi dan membimbing siswa dalam mengerjakan soal secara individual maupun kelompok dan tahap terakhir yaitu mengkomunikasikan guru memberikan kesempatan kepada siswa untuk menyampaikan hasil jawabannya.

Ibu Made Suardani, S.Pd dari SMA Negeri 2 Singaraja dalam mengimplementasikan pendekatan saintifik pada kegiatan pembelajaran yaitu kegiatan mengamati guru meminta peserta didik untuk membaca teks bacaan tentang materi yang akan dipelajari setelah membaca guru menjelaskan bersama-sama mengenai materi yang akan dipelajari. Langkah selanjutnya kegiatan menanya siswa diminta menanyakan hal-hal yang ingin diketahui berkaitan dengan apa yang sedang dipelajari, kegiatan mengumpulkan data guru meminta peserta didik mengerjakan soal secara individual atau di dalam kelompok, dalam kegiatan menganalisis data guru mengawasi dan membimbing siswa dalam mengerjakan soal secara individual maupun kelompok dan kegiatan terakhir yaitu mengkomunikasikan guru memberikan kesempatan kepada siswa untuk menyampaikan hasil jawabannya. Bapak Drs. Nyoman Gede Darma Kusuma dalam mengimplementasikan pendekatan saintifik yaitu Kegiatan mengamati guru meminta peserta didik untuk membaca teks bacaan tentang materi yang akan dipelajari setelah membaca guru menjelaskan bersamasama mengenai materi yang akan dipelajari. Selanjutnya kegiatan menanya siswa diminta menanyakan hal-hal yang ingin diketahui berkaitan dengan apa yang sedang dipelajari, kegiatan mengumpulkan data guru meminta peserta didik mengerjakan soal dengan cara berdiskusi dengan teman sebangku, guru mengawasi dan membimbing siswa dalam mengerjakan soal dengan cara berdiskusi dengan teman sebangku, selanjutnya guru memberikan kesempatan kepada siswa untuk menyampaikan hasil jawabannya.

$$
\text { Bapak Nyoman Sudarsana, }
$$

S.Pd dari SMA Negeri 3 Singaraja dalam mengimplementasikan pendekatan saintifik yaitu mengamati guru meminta peserta didik untuk membaca teks bacaan tentang materi yang akan dipelajari setelah membaca guru menjelaskan bersama-sama mengenai materi yang akan dipelajari, guru meminta peserta didik mengerjakan soal secara individual, guru mengawasi dan membimbing siswa dalam mengerjakan soal secara individual dan kegiatan terakhir yaitu mengkomunikasikan guru memberikan kesempatan kepada siswa untuk menyampaikan hasil jawabannya. Bapak Drs. Ketut Setyawan dari SMA 
Negeri 3 Singaraja dalam mengimplementasikan pendekatan saintifik yaitu mengamati guru menjelaskan mengenai materi yang akan dipelajari, siswa mendengarkan penjelasan dari guru dan memperhatikannya, selanjutnya guru menanyakan hal-hal yang berkaitan dengan apa yang sedang dipelajari, siswa diminta membaca buku pegangan siswa dan berdiskusi dengan teman sebangku untuk menjawab soal yang diberikan guru. Peserta didik yang sudah mengetahui jawabannya diminta untuk membacakan hasil jawabannya.

Ibu Dra. Ida Ayu Wasanti dari SMA Negeri 4 Singaraja dalam mengimplementasikan pendekatan saintifik yaitu mengamati guru meminta peserta didik untuk membaca teks bacaan tentang materi yang akan dipelajari setelah membaca guru bertanya kepada siswa mengenaihalhal yang berkaitan dengan materi yang dipelajari guru dan siswa bersamasama menjelaskan materi yang sedang dipelajari guru memberikan kesempatan kepada siswa untuk menyimpulkan materi yang sudah dipelajari hari ini. mengamati guru meminta peserta didik untuk membaca teks bacaan tentang materi yang akan dipelajari setelah membaca guru menjelaskan bersamasama mengenai materi yang akan dipelajari, selanjutnya guru bertanya kepada siswa berkaitan dengan apa yang sedang dipelajari, siswa dan guru bersama- sama menjelaskan materi yang dipelajari. Guru memberikan dua contoh soal yang harus dikerjakan oleh siswa, pada proses siswa mengerjakan soal guru membimbing dan mengawasi siswa, guru meminta dua orang siswa untuk maju kedepan menuliskan jawabannya. Dra. Sri Jayawati Kegiatan mengamati guru meminta peserta didik untuk membaca teks bacaan tentang materi yang akan dipelajari setelah membaca guru menjelaskan bersamasama mengenai materi yang akan dipelajari, selanjutnya guru bertanya kepada siswa berkaitan dengan apa yang sedang dipelajari, siswa dan guru bersama- sama menjelaskan materi yang dipelajari. Guru memberikan dua contoh soal yang harus dikerjakan oleh siswa, pada proses siswa mengerjakan soal guru membimbing dan mengawasi siswa, guru meminta dua orang siswa untuk maju kedepan menuliskan jawabannya.Di dalam Permendikbud 103 tahun 2014 aktivitas eksplorasi dapat dilakukan melalui eksperimen. Menganalisis yaitu proses berfikir yang logis dan sistematis atas fakta-fakta emperis yang dapat diobservasi untuk memperoleh simpulan. Kegiatan mengkomunikasikan adalah menyampaikan hasil pengamatan, guru diharapkan memberi kesempatan kepada peserta didik untuk mengkomunikasikan apa yang telah mereka pelajari, kegiatan ini dapat dilakukan melalui menuliskan atau menceritakan apa yang ditemukan dalam kegiatan mencari informasi, mengasosiasi, dan menemukan pola.

Dalam proses pembelajarannya yaitu mengamati, menanya, mengumpulkan data, dimana implementasi pendekatan saintifik ini harus dilakukan pada kegiatan inti proses belajar mengajar, guru sudah melaksanakan pembelajaran menggunakan pendekatan saintifik tetapi pelaksanaannya belum maksimal tidak semua guru melakukan suatu proses implementasi pendekatan saintifik yang benar mulai dari tahap mengamati sampai mengkomunikasikan, jika didampingi secara kontinu guru akan melakukan lebih baik. Guru yang sudah baik dalam mengimplementasikan pendekatan saintifik kurikulum 2013 adalah Ibu Eresmawati guru ekonomi dari SMA Negeri 1 Singaraja dan Bapak Drs. Nyoman Gede Darma Kusuma guru ekonomi dari SMA Negeri 2 Singaraja. Guru ekonomi sudah cukup memahami tentang pendekatan saintifik tetapi masih perlu banyak belajar lagi karena guru butuh penyesuaian dengan kurikulum yang baru ini. Dalam kurikulum baru ini identik dengan pendekatan saintifik jadi semua guru menggunakan pendekatan tersebut walaupun belum sepenuhnya sesuai. 


\section{SIMPULAN DAN SARAN Simpulan}

Berdasarkan hasil penelitian yang diperoleh mengenai kinerja guru ekonomi dalam mengimplementasikan pendekatan saintifik kurikulum 2013 di SMA Kota Singaraja sudah cukup baik pada mata pelajaran ekonomi, guruguru ekonomi sudah mengimplementasikan pendekatan saintifik kurikulum 2013 karena dalam kurikulum 2013 harus mengimplementasikan pendekatan saintifik dengan dengan lima tahap sebagaimana disampaikan dalam Permendikbud Nomor 103 tahun 2014 yaitu. Mengamati, menanya, mengumpulkan data, menganalisis data, dan mengkomunikasikan. Sesuai dengan hasil yang diperoleh melalui observasi dan wawancara guru yang sudah baik dalam mengimplementasikan pendekatan saintifik kurikulum 2013 adalah Ibu Eresmawati guru ekonomi dari SMA Negeri 1 Singaraja dan Bapak Drs. Nyoman Gede Darma Kusuma guru ekonomi dari SMA Negeri 2 Singaraja.

\section{Saran}

Bagi Kepala Sekolah hendaknya melakukan monitoring dan pelatihan terhadap pelaksanaan pembelajaran dan penilaian dalam kurikulum 2013 untuk meningkatkan kemampuan guru dalam mengimplementasikan kurikulum 2013,bagi guru hendaknya lebih kreatif, terus belajar dan beradaptasi dengan kurikulum 2013 khususnya pada pelaksanaan pembelajaran dengan menggunakan pendekaan saintifik , dan bagi peneliti selanjutnya, pendekatan saintifik dapat menjadi materi penelitian pada berbagai jenjang sekolah dan berbagai tema. Karena masih banyak guru yang belum sepenuhnya mengimplementasikan dengan baik pendekatan saintifik pada kurikulum 2013.

\section{DAFTAR PUSTAKA}

Arikunto, S dan Jabar, C. 2010. Evaluasi Program Pendidikan. Jakarta : Bumi Aksara.
Hani, Handoko T. 2000. Manajmen Personalia dan Sumber Daya Manusia. Yogyakarta: Amara Masagung.

Kemendikbud. 2012. Dokumen Kurikulum 2013. Tersedia di www. storage/emulated/0/ download/bahan_uji_publik_kur2013.pdf. (diakses tanggal 15 Juli 2016).

Kemendikbud. 2013. Lampiran Permendikbud 65 Tahun 2013

Tentang Kerangka Dasar dan Struktur Kurikulum SMP/Mts. Tersedia di http:// kemendikbud.go.id/ kemendikbud/ siaranpers/ 3590. (diakses 4 Desember 2016)

Kemendikbud. $2014 . \quad$ Lampiran Permendikbud 103 Tahun 2014 Tentang Implementasi Kurikulum Pedoman Umum Pembelajaran. Tersedia di http:// kemendikbud.go.id/ kemendikbud/ siaranpers/ 3590. (diakses 4 Desember 2016)

Martoyo, Susilo. 2007. Manajemen Sumber Daya Manusia. Edisi 5, Cetakan Pertama, BPFE Yogyakarta.

Purwanto, Ngalim. 2002. Administrasi dan Suvervisi Pendidikan Bandung. Bandung: PT Rosdakarya.

Ridwan, Abdulah Sani. 2014. Pembelajaran Saintifik untuk Kurikulum 2013. Jakarta: Bumi Aksara.

Soetjipto, Budi W. 2003. Paradigma Baru Manajemen Sumber Daya Manusia. Yogyakarta : Amara books.

Sugiyono. 2011. Metode Penelitian Pendidikan. Bandung: Alfabeta

Undang-Undang Republik Indonesia Nomor 14 Tahun 2005 Tentang Guru dan Dosen. Tersedia di www.storage/emulated/0/downlo ad/uu14-2005 GuruDosen. Pdf. (diakses tanggal 2 Agustus 2016 